УДК 340.5

\title{
CONSEQUENCES OF THE ALAND ISLANDS' MEMBERSHIP IN THE EUROPEAN UNION: OUTLINE OF THE PROBLEM
}

\author{
K. Szwed \\ University of Rzeszów, \\ 16C, Tadeusza Rejtana al., Rzeszow, 35001, Poland, \\ e-mail:szwed@ur.edu.pl
}

The article examines the process and consequences of the integration of the Aland Islands into the European Community.

The author considers the special position of the Aland Islands in the Finnish and international law as well as the ever-growing demand to respond to the process of globalisation and Europeanisation. Its legal position and adopted model of autonomy is unique as it is an example of an arrangement through which a territorial conflict between two states, namely Sweden and Finland, was settled in a peaceful way. Additionally, its status is connected with the idea of demilitarisation and neutralisation of the archipelago.

In the article much attention is paid to the stages of the integration process as well as the adoption of the Aland Protocol. The author describes the peculiarities of the negotiation objectives, the role of Finland in the accession of the autonomy and the structure and the main content of the Aland Protocol. The autonomy strengthen its position in the international area but also gained additional guarantees for its demilitaralised and neutralised status. However the inhabitants of the Aland Islands would still expect the Finnish to allow them to have their own representative in the European Parliament.

Keywords: the Aland Islands, Finland, autonomy, the European Union, derogations

The main subject of this article is to characterize the integration processes of the Aland Islands and consequences they have brought to its small community. The analysis covers legal circumstances, including especially status of the archipelago under international law, as well as internal factors determining attitude towards the integration. In the article there is adopted a research hypothesis stating that the accession to the European Union strengthened the international legal position of the Aland Islands, and guaranteed protection of the unique, in the country, Swedish identity of the inhabitants of the autonomy and secured their economic interests.

In comparison to other European autonomies, the Aland Islands differentiate with particular reasons for gaining independence, as well as with its demilitarized and neutralized status [7, p. 470-472]. Granting autonomy to the Aland Islands was an outcome of political forces developed after the World War I, the conflict of interests between Sweden and Finland, and the need to safeguard the strategic area for the security of the region [17, p. 64].

The archipelago was in the Swedish sphere of influence till the moment when Sweden lost Finland and Aland Islands in favour of Russia in Crimean War in 1809. The legacy of this long-term dependence of the archipelago is Swedish language and culture which is predominant here. The archipelago was demilitarized in 1856. In 1921 under the decision of the League of Nations, rights to the Aland Islands were granted to Finland which had already provided the archipelago with certain autonomy a year earlier [15, p. 107]. Helsinki agreed to preserve Swedish identity, culture and language of the inhabitants of the autonomy.

(C) Szwed K., 2018 
According to Filip Jasinski the developed «Aland model is an example of effective cooperation between the autonomous region and the rest of the country» [9, p. 12]. Undoubtedly, both parties act with respect for the fundamental principles of the rule of law, democracy and pluralism.

The most important national legal act determining the status of the archipelago is the Constitution of the Republic of Finland of 11 June 1999. Under section 120 of the Constitution of Finland «[t]he Aland Islands have self-government in accordance with what is specifically stipulated in the Act on the Autonomy of the Aland Islands». In addition, according to section 75 of the Constitution, «[t]he legislative procedure for the Act on the Autonomy of the Aland Islands and the Act on the Right to Acquire Real Estate in the Aland Islands is governed by the specific provisions in those Acts. The right of the Legislative Assembly of the Aland Islands to submit proposals and the enactment of Acts passed by the Legislative Assembly of Aland are governed by the provisions in the Act on the Autonomy of the Aland Islands» [13, p. 90, 105].

The current Self-Government (Autonomy) Act (Ahvenanmaan itsehallintolaki/ Självstyrelselag för Aland) was enacted by the Parliament of Finland on 16 August 1991 (No. 1144/1991) and entered into force on the $1^{\text {st }}$ of January 1993. So far it has been amended five times [18, p. 86]. The two last amendments introduced in 2004 and 2009 resulted as a consequence of the EU accession of Finland and the Aland Islands.

Finland was one of the metropolitan states which left autonomies free to decide whether they want to participate in the European integration process or not [24, p. 134136]. The Aland Islands decided independently about accession to the EU structures considering that potential economic and political benefits, especially reinforcement of the autonomy, outweigh possible obligation to conform to norms and standards of European cooperation and trade.

It should be emphasized that in the age of ongoing globalization and Europeanisation, autonomous territories are showing increasing aspirations to mark their presence on the international scene. Whereby, membership in the EU structures has an institutional character and is an act of will, whereas globalization progresses in and of itself, and at grassroots. Therefore, the Aland Islands' accession to the European Union constituted an act of conscious acceptance of possible inconveniences which may result from this decision.

Finland is obliged to respect the autonomous status of the Aland Islands in its foreign policy. A representative of the Aland Islands participates in international relations in which government of Finland is a party, and which may affect the autonomy. International agreements concluded by Finland which would be contrary to the SelfGovernment Act of the Aland Islands do not come into force on the territory of the autonomy [22, p. 121 et al.]. This particular position of the Aland Islands in the metropolitan state is a consequence of National League's decision and provisions of international law $[10$, p. 88-90]. The European Union accepted and recognized this special international legal position of the Aland Islands during accession process of the Republic of Finland. What is more, the Aland Islands are the only autonomous territory, which status is guaranteed by the primary Community law [6, p. 65].

The agreement on the future status of the Aland Islands in the EU structures was subject to complex negotiations. Difficulties resulted from technical and legislative issues [8, p. 81]. A thorough analysis of the Aland Islands' accession process allows distinguishing its three basic stages. In the initial stage, from August 1992 till October 1993, internal negotiations were held between the Aland Islands and Finland. Then, Finland entered into negotiations with the Member States of the European Union, which 
lasted from October 1993 till February 1994. In the last stage controversial issues regarding membership in the EU structures were resolved between the metropolis and the autonomy. It concerned questions, which according to the Self-Government Act, remained under exclusive legislative powers of Finland (February-November 1994) [5, p. 190]. Developing a joint approach of Finland and the Aland Islands towards the accession forced introduction of formalized contact in form of communications between local parliament and government.

The Aland authorities were aware of the far-reaching consequences of the EU membership. There was a concern regarding especially the implementation of Community customs regulations which may have had a negative impact on the broader touristic sector. Therefore, the autonomy adopted an active approach in the negotiations with the European Union. Contrary to the metropolitan country, which described its expectations of the accession rather in a general way, the autonomy assumed reaching certain goals and specific derogations of the EU law [14, p. 132]. Membership in the EU constituted a chance for economic development for the Aland Islands and an opportunity to strengthen position of the autonomy on the international front. Implementation of the following postulates was to guarantee the fulfillment of the goals:

- demilitarized and neutralized status of the archipelago;

- protection of the legislative autonomy before the Community law;

- preservation of Swedish as the only official language;

- limitations in holding local and municipal elections,

- restrictions related to acquisition and ownership of a real estate;

- restrictions as regards right of trade on the territory of the archipelago;

- right to own separate fiscal and trade provisions;

- the Aland Islands' influence on decision-making process of the European Union.

The Aland government stressed that the fulfillment of the abovementioned postulates would be possible only with the active cooperation of Finnish government. In face of ambitious requirements made by the Aland Islands, among 30 groups responsible for preparing negotiations regarding Finland's accession to the EU there was created an Aland working party so called Jääskinen Group. The Aland government was also allowed to participate in numerous negotiations held by the metropolis [2, p. 71].

The accession to the EU was preceded by referendums. The Aland voted twice - first on the $16^{\text {th }}$ of October 1994 on Finland's accession to the EU. The turnout was $61,2 \% .51,9 \%$ of the entitled to vote were in favour of the accession. Finally, on the $18^{\text {th }}$ of November 1994 the parliament of Finland has approved the Accession Treaty [11, p. 387].

The next referendum, this time regarding the accession of the Aland Islands was set at $20^{\text {th }}$ of November 1994 [24]. The date was set intentionally on such a day to ensure the community of archipelago gets familiar with the results of the accession referendum which had been held a week before in Sweden [3, p. 161]. The fact that the Swedish supported the idea of their accession to the Community was an additional argument for the Aland Islands in favour of the integration [4, p. 30]. Therefore, with the turnout of $49,1 \%$ the considerable majority, almost $73,6 \%$ of all the voting in the Aland Islands endorsed the accession efforts [8, p. 82].

Due to the lack of detailed regulations regarding the accession of an autonomy to supranational organizations, the procedure of the Aland Islands' accession to the EU was conducted pursuant to Article 59 of the Self-Government Act of the Aland Islands. This stipulates that in case an agreement or another international commitment which are binding Finland include regulations being in competence of the Aland Islands, the permission of the local parliament for its validity on the territory of the archipelago is 
necessary. Moreover, if the provisions of such an agreement enter in conflict with the Self-Government Act, they come into force only if the parliament of the autonomy accepts them with the qualified majority of 3/4 (75\%) votes cast, and if Eduskunta approves them in the manner provided for in Article 95 (2) of the Constitution of the Republic of Finland [13, p. 97]. Therefore, the cooperation between the metropolis and the autonomy was indispensable. Especially in these circumstances when Helsinki needed the required support of Aland deputies.

On the 2nd of December 1994 the vast majority of the Aland Parliament voted in favour of the accession to the Community, there were 28 votes for and 4 against [19, p. 125]. On the $1^{\text {st }}$ of January 1995 Finland and the Aland Islands became full members of the European Union.

The legal basics of the unique status of the archipelago are included in the Protocol on the Aland Islands. The document constitutes an integral part of Finnish Accession Treaty. Under the Protocol the autonomy was granted derogations in several key problem areas. The privileges given to the Aland Islands have been firmly rooted in in the Community legal order since the mentioned documents forms a part of primary European Union law.

It consists of three articles preceded by a preamble. There are reasonable doubts already as to the wording of the introduction, which states that the Aland Islands have a unique status in the international law. In Fiona Murray's opinion this statement constitutes an attempt to justify granting the autonomy broad range of derogations within the European Union legislature [14, p. 136]. In the academic literature it is rightly noted that such a clear emphasis put on the unique status of the archipelago within international law aims to avoid considering this case as a precedent for other territories [1, p. 108].

At the same time, it is this provision that creates the greatest controversy and divergences in the interpretation between Finnish and Aland parties [19, p. 138]. Broad interpretation of the preamble indirectly confirms the demilitarized and neutralized status of this area. However, this solution is not beneficial from the point of view of Finland, where the postulates of restoring sovereignty over the Aland Islands in terms of military have appeared.

Another relevant issue which needed to be agreed was, taking into consideration non-discriminatory nature, leaving it for proper Aland authorities to decide about right of acquisition of land by natural persons who do not enjoy regional citizenship in Aland Islands (hembygdsrätt) and their right to run business and provide services. These restrictions resulted from the need to protect unique identity and culture of the Swedishspeaking community, as well as maintaining the ownership right to a real estate in domestic hands [16, p. 136]. The change in the ownership may cause serious, also negative, consequences when it comes to small, in terms of numbers, communities living in the autonomous territories. As a result, it could lead to a change in the distinctive character of a given territory.

The rights deriving from a domicile (regional citizenship) constitute elements of Aland autonomy. People having the right of domicile enjoy special privileges in comparison to other citizens of Finland. It should be noted that the regional citizenship is a prerequisite for the right to stand and vote in elections for the Lagting and municipal elections. Regarding the latter, before the accession to the EU citizens of Finland, Sweden, Denmark, Norway and Iceland, who lived in the territory of the Aland Islands could participate in these elections. However, the Protocol on the Aland Islands did not confirm these privileges.

Eventually, exceptions from the general rules of an EU citizen's right to vote or to stand as a candidate in local government elections were allowed with the agreement of 
the European Union. As a consequence, people with rights of domicile or people living in the Aland Islands for at least 3 years may participate in local government elections, whereas only people with rights of domicile and Finnish citizens may take part in elections to the Aland parliament.

Article 2 of the Protocol provides guarantees for development and competitiveness of the local economy. The archipelago was exempted from the EU regulations regarding VAT, excise duty and other forms of indirect taxation. The Aland Islands were described as a third country which is not covered by the harmonizing directive for indirect taxes. Trade in goods between the Aland Islands and other EU countries is based on a Single Administrative Document (SAD). The exception constitutes trade with Finland, to which greatly simplified rules are applied. It can be considered to be a success that tax free sales on board aircraft and ferries were preserved. The European Union stressed that granted derogations should not have any negative impact on the interests of the EU and its common policy. The document restates and emphasizes the non-discrimination principle [5, p. 209; 14, p. 138;].

In response to Aland authorities' requests for increasing the autonomy's participation in decision-making mechanisms at the national level in questions regarding membership in the European Union, the provisions of the chapter 9a called European Union affairs of the Self-Government Act were reviewed [20, p. 44]. The Aland government was granted the right to access information about European institutions' works on issues that concern them. Furthermore, the government was ensured to participate in Finnish government's projects concerning European matters as far as may affect the archipelago [23, p. 30]. The provisions included in this chapter regulate issues concerning violations of the Treaty and determine the Aland Islands' joint share of the state's responsibility, in proportion to acts or omissions of this dependent territory. The autonomy has got also a representative in the Committee of the Regions [7, p. 476].

The Aland government insisted on creating a separate electoral constituency for the elections to the European Parliament [10, p. 100-101]. Finland repeatedly expressed their opposition against transferring one of the Finnish mandates in the European Parliament to the Aland Islands. This attitude was harshly criticized by the Aland authorities. Dissatisfaction among inhabitants led to low attendance in the elections to European Parliament in 1999 and 2004. It amounted to $22 \%$ in 1999 and slightly over $35 \%$ in 2004. Only in subsequent elections conducted in 2009 and 2014 the number of the voting increased. The turnout reached the level of $48,2 \%$ and $57,3 \%$, respectively [21, p. 31].

The significant stage of the integration was the Aland Islands' entry into the euro area in 2002. The Aland were not particularly attached to the Finnish Mark, especially as that there is Swedish Kroner still in circulation. The Aland parliament accepted the adoption of the Amsterdam Treaty, the Nice Treaty, and the Lisbon Treaty.

The adoption of the latter document was used as a pretext to strengthen the position of the Aland Islands. It was eventually adopted by the Aland Islands, however only after intentionally extended work of the Parliamentary Commission [12]. At that time Aland authorities demanded the extension of powers of the autonomy to right of the defence before the Court of Justice (ECJ) on issues related to competencies respective to the Aland Islands. Before in the cases in ECJ the Aland Islands were represented only by Finland. It was also requested to approve of the possibility to use Swedish language for matters concerning the violations of the EU provisions [23, p. 30]. Both proposals were finally adopted by the Finnish parliament and they come into force on the $1^{\text {st }}$ of December 2009.

The Aland Islands are obliged to implement Union legislature, however only in those areas which belong to the competencies respective to the government of the 
autonomy. In case of such a small bureaucratic apparatus the implementation of the European Union legislature is a very time-consuming process and requires many material and technical measures. In practice, however, the Aland Islands transferred fewer legislative powers to the European Union than Finland did, because the majority of powers being proper for the autonomy fall outside the Union competence.

The decision regarding integration proved to be desirable both from economic and from political point of view of the Aland Islands. Concerns that the accession could weaken the distinct cultural identity of the Aland or threaten its trade interests turned out to be unfounded. On the contrary, by being incorporated to aquis communitaire the autonomy strengthened its position on the international stage, and what is particularly relevant, it received a confirmation of its demilitarized and neutralized status. The Aland authorities proved excellent negotiating skills and led to adopt solutions beneficial for the autonomy. It was of particular importance to secure the archipelago against weakening and or even losing its unique Swedish nature. This was achieved through negotiating restrictions related to the right to acquire land and right to run business by persons without the right of domicile.

The already existing solutions applied on the Aland Islands were respected by the European Union, including duty-free trade of goods. Additionally, the Aland Islands were exempted from harmonizing legislation regarding indirect taxation. Unfortunately, they still have no representation in the European Parliament. Certainly it would strengthen the Aland Islands' voice in the European institutions and their influence on shaping mutual policy. However, having a representative in an advisory body called the Committee of Regions may be considered as a certain form of compensation.

The accession to the EU is evaluated positively by the inhabitants of the Aland Islands themselves. An opinion poll conducted in 2013 showed that $51 \%$ of the Aland considered membership in the EU structures as beneficial, whereas a negative opinion was expressed by $20 \%$ of the respondents.

The case of the Aland Islands is extremely interesting also in respect of the remaining Nordic autonomies - Greenland and Faeroe Islands. Communities of Danish autonomies have formed negative views on integration with the European Union. The reasons for that were similar concerns regarding possible loss of entity as well as significant influence of Brussels on the primary sector of the economy or access to mineral resources. The Aland Islands becoming a member of the EU proved that it is possible to combine the Europeanization processes with the protection of economic interests, culture and preservation of a unique identity. What is more, The Aland Protocol constitutes an integral part of Finnish Accession Treaty, therefore any amendment requires an agreement of all State Members of the European Union, including Finland and the Aland Provincial Government.

\section{Список використаних джерел}

1. Anckar D., Bartmann B. The Aland Islands in the European Union // Framing Independent Aland. Mariehamn, 2000.

2. Bonusiak G. Statut Wysp Alandzkich. Rzeszów, 2009.

3. Czarny R. M. Szwecja - Unia Europejska. Kielce, 2002.

4. Dośpiat-Borysiak K. Państwa nordyckie a Unia Europejska. Warszawa, 2007.

5. Fagerlund N. The Special Status of the Aland Islands in the European Union / N. Fagerlund; L. Hannikainen, F. Horn [and other] // Autonomy and Demilitarisation in International Law: The Aland Islands in a Changing Europe. The Hague: London; Boston, 1997. 
6. Hannikainen L. The International Legal Basis of the Autonomy and Swedish Character of the Aland Islands / L. Hannikainen, F. Horn [and other] // Hannikainen L. Autonomy and Demilitarisation in International Law: The Aland Islands in a Changing Europe. The Hague: London; Boston, 1997.

7. Hepburn E. Forging autonomy in a unitary state: the Aland Islands in Finland // Comparative European Politics. 2014. Vol. 12. Iss. 4-5.

8. Jańczak $J$. Na granicy Unii Europejskiej - pozycja europejskich terytoriów autonomicznych w dobie globalizacji i integracji. Przypadek Wysp Alandzkich // Środkowoerupejskie Studia Polityczne. 2007. № 2.

9. Jasiński F. Status Wysp Alandzkich jako przykład suwerenności w ramach Unii Europejskiej // Wspólnoty Europejskie. 1998. № 5 (81).

10. Joenniemi P., Archer C. The Aland Islands Issue // Nordic Peace. Hampshire, 2003.

11. Jussila O., Hentilä S., Nevakivi J. Historia polityczna Finlandii 1809-1999. Kraków, 2001.

12. Kirk L. Finnish islands cause headache for EU treaty approval: Euobserver. URL: https://euobserver.com/institutional/26601. - Назва з екрана.

13. Konstytucja Finlandii: passed in 1999 / translation J. Osiński. Warszawa, 2003.

14. Murray F. The European Union and Member State Territories: A New Legal Framework Under the UE Treaties. The Hague. 2012.

15. Myntti K. The Aland Model - Its Background and Special Characteristics / H. Jansson, J. Saminen [and other] // Myntti K. The Second Aland Question. Autonomy or Independence. Mariehamn, 2002.

16. Myntti K., Scheinin M. The Right of Domicyle in the Aland Islands / L. Hannikainen, F. Horn [and other] // Myntti K., Scheinin M.Autonomy and Demilitarisation in International Law: The Aland Islands in a Changing Europe. The Hague: London; Boston, 1997.

17. Nordquist K. A. Autonomy as a Conflict-Solving Mechanism - an Overview / M. Suksi [and other] // Nordquist K. A. Autonomy: Applications and Implications. The Hague: London; Boston, 1998.

18. Palmgren $S$. The Autonomy of the Aland Islands in the Constitutional Law of Finland / L. Hannikainen, F. Horn [and other] // Palmgren S. Autonomy and Demilitarisation in International Law: the Aland Islands in a Changing Europe. London, 1997.

19. Scarpulla C. The Special Status of Aland in Finland and the European Union / H. Jansson, J. Salminen [and other] // Scarpulla C. The Second Aland Question. Autonomy or Independence?. Marienamn, 2002.

20. Silverström S. Implementation of EU Legislation in the Aland Islands. Mariehamn, 2008.

21. Silverström S. Aland in the European Union // Mariehamn, 2013. URL: https://julkaisut.um.fi/media/attachments/3cd4e/ET-100004-EN.pdf. - Назва з екрану.

22. Sobczyński M. Rola i miejsce Wysp Alandzkich w Unii Europejskiej / R. Żelichowski [and other] // Sobczyński M. Małe państwa Europy Zachodniej i terytoria o statusie specjalnym. Ich rola i miejsce w Unii Europejskiej. Warszawa, 2008.

23. Stephan S. Regional Voices in the European Union. Mariehamn, 2010.

24. Szwed K. Stanowisko autonomii nordyckich wobec integracji europejskiej // Zeszyty Naukowe Uniwersytetu Rzeszowskiego. Seria Prawo. 2013. № 77.

\section{References}

1. Bartmann, B. (2000). The Aland Islands in the European Union. In D. Anckar, B. Bartmann, Framing Independent Aland. Mariehamn.

2. Bonusiak, G. (2009). Statut Wysp Alandzkich. Rzeszów.

3. Czarny, R. M. (2002). Szwecja - Unia Europejska. Kielce.

4. Dośpiał-Borysiak, K. (2007). Państwa nordyckie a Unia Europejska. Warszawa. 
5. Fagerlund, N. (1997). The Special Status of the Aland Islands in the European Union. In L. Hannikainen, F. Horn (red.) Autonomy and Demilitarisation in International Law: The Aland Islands in a Changing Europe. The Hague - London - Boston.

6. Hannikainen, L. (1997). The International Legal Basis of the Autonomy and Swedish Character of the Aland Islands. In L. Hannikainen, F. Horn, Autonomy and Demilitarisation in International Law: The Aland Islands in a Changing Europe. The Hague - London Boston.

7. Hepburn, E. ( 2014). Forging autonomy in a unitary state: the Aland Islands in Finland. Comparative European Politics, 12, Issue 4-5.

8. Jańczak, J. (2007). Na granicy Unii Europejskiej - pozycja europejskich terytoriów autonomicznych w dobie globalizacji i integracji. Przypadek Wysp Alandzkich. Środkowoerupejskie Studia Polityczne, 2.

9. Jasiński, F. (1998). Status Wysp Alandzkich jako przykład suwerenności w ramach Unii Europejskiej. Wspólnoty Europejskie, 5 (81).

10. Joenniemi, P. (2003). The Aland Islands Issue. In C. Archer, P. Joenniemi (red.). Nordic Peace. Hampshire.

11. Jussila, O., Hentilä, S., \& Nevakivi J., 2001.Historia polityczna Finlandii 1809-1999. Kraków.

12. Kirk, L. (2008). Finnish islands cause headache for EU treaty approval. EUobserver, 12 August 2008. Retrieved from: https://euobserver.com/institutional/26601, (05.02.2018).

13. Konstytucja Finlandii. 1999. (2003). Translation and introduction J. Osiński. Warszawa.

14. Murray, F. (2012). The European Union and Member State Territories: A New Legal Framework Under the UE Treaties. The Hague.

15. Myntti, K. (2002). The Aland Model - Its Background and Special Characteristics. In H. Jansson, J. Saminen (red.). The Second Aland Question. Autonomy or Independence? Mariehamn.

16. Myntti, K., \& Scheinin. M. (1997). The Right of Domicyle in the Aland Islands. In L. Hannikainen, F. Horn (red.). Autonomy and Demilitarisation in International Law: The Aland Islands in a Changing Europe. The Hague - London - Boston.

17. Nordquist, K. A. (1998). Autonomy as a Conflict-Solving Mechanism - an Overview. In M. Suksi (red.). Autonomy: Applications and Implications. The Hague - London - Boston.

18. Palmgren, S. (1997). The Autonomy of the Aland Islands in the Constitutional Law of Finland. In: L. Hannikainen, F. Horn (red.). Autonomy and Demilitarisation in International Law: the Aland Islands in a Changing Europe. London.

19. Scarpulla, C. (2002). The Special Status of Aland in Finland and the European Union. In H. Jansson, J. Salminen. The Second Aland Question. Autonomy or Independence? Marienamn.

20. Silverström, S. (2008). Implementation of EU Legislation in the Aland Islands. Mariehamn.

21. Silverström, S. (2018). Aland in the European Union. Mariehamn 2013. Retrieved from: https://julkaisut.um.fi/media/attachments/3cd4e/ET-100004-EN.pdf.

22. Sobczyński, M. (2008). Rola i miejsce Wysp Alandzkich w Unii Europejskiej. In R. Żelichowski (red.). Małe państwa Europy Zachodniej i terytoria o statusie specjalnym. Ich rola i miejsce w Unii Europejskiej. Warszawa.

23. Stephan, S. (2010). Regional Voices in the European Union. Mariehamn.

24. Szwed, K. (2013). Stanowisko autonomii nordyckich wobec integracji europejskiej. Zeszyty Naukowe Uniwersytetu Rzeszowskiego, Seria Prawo, 77. 


\title{
НАСЛІКИ ЧЛЕНСТВА АЛАНДСЬКИХ ОСТРОВІВ У ЄВРОПЕЙСЬКОМУ СОЮЗІ: ОКРЕСЛЕННЯ ПРОБЛЕМИ
}

\author{
К. Швед
}

\author{
Жешувський університет, \\ ал. Тадеуша Рейтана, 16С, Жешув, 35001, Республіка Польщุа, \\ e-mail: szwed@ur.edu.pl
}

Розглянуто процес та наслідки інтеграції Аландських островів до Європейського співтовариства. Ця фінська автономія вирішила вступити до Європейського Союзу разом з Гельсінкі після ретельного розгляду можливих переваг та недоліків такого рішення. Для мешканців архіпелагу цей крок створював загрозу чіткому шведському характеру території, а також її економіці, яка сильно залежить від туризму.

Розглянуто особливий статус Аландських островів у фінському та міжнародному законодавстві, а також постійно зростаючу вимогу реагувати на процес глобалізації та європеїзації. Варто зазначити, що Аландські острови $€$ найстаршою і найменшою автономією Північного регіону, та єдиною, яка приєдналася до Європейського Союзу й залишалася в ній. Її правовий статус та прийнята модель автономії $€$ унікальною, оскільки це є прикладом вирішення територіального конфлікту між двома державами, а саме Швецією та Фінляндією, який був врегульований мирним шляхом. Окрім того, її статус пов'язаний з ідеєю демілітаризації та нейтралізації архіпелагу. 3 цих причин рішення про вступ до ЄС мало вирішальне значення для нинішнього та майбутнього статусу Аландських островів.

Значну увагу приділено етапам інтеграційного процесу, а також прийняттю протоколу про Аланди. Описано особливості переговорів, роль Фінляндії в процесі приєднання автономії та структуру і основний зміст протоколу в Аланді. Цей документ має особливе значення, оскільки він сильно вплинув на позицію Аландських островів у межах Європейського Союзу. Варто наголосити, що цей короткий акт є частиною первинного законодавства Співтовариства та містить спеціальні відступи від положень $€ С$. Про всяк випадок, виняток з правил ЄС стосовно ПДВ, акцизного збору та інших форм непрямого оподаткування, а також залишення правильним органам влади в Аланді щодо прийняття права на придбання землі фізичними особами, які не мають регіонального громадянства та їх право розпочати бізнес і надавати послуги.

Отже, вибір шляху європейської інтеграції виявився корисним для Аланд. Автономія не тільки зміцнила свої позиції на міжнародній арені, але й отримала додаткові гарантії щодо ії̈ демилітаризованого та нейтралізованого статусу. Вступ до $€ С$ не порушив культурну ідентичність мешканців та не становив загрози економіці. Навпаки, Аландським островам вдалося отримати істотні відступи, які захищають їх автономію, економіку та шведський характер. Проте мешканці Аландських островів все ж сподівалися, що їм дозволять мати свого представника в Європейському парламенті.

Ключові слова: Аландські острови, Фінляндія, автономія, Європейський Союз. 